\title{
EVALUASI KADAR LOGAM BERAT DAN PESTISIDA PADA SAMPEL AIR SUNGAI BRIBIN GUNUNG KIDUL FUNGSI WAKTU DAN LOKASI SAMPLING (BAGIAN I)
}

\author{
Agus Taftazani, Tri Rusmanto \\ P3TM-BATAN
}

\begin{abstract}
ABSTRAK
EVALUASI KADAR LOGAM BERAT DAN PESTISIDA PADA SAMPEL AIR SUNGAI BRIBIN GUNUNG KIDUL FUNGSI WAKTU DAN LOKASI SAMPLING (BAGIAN I). Telah dilakukan penentuan kandungan logam berat $\mathrm{Ca}$, $\mathrm{Mg}, \mathrm{Mn}, \mathrm{Fe}, \mathrm{Hg}, \mathrm{Cd}, \mathrm{Cr}, \mathrm{Co}$, senyawa karbofuran dan DDT dalam air dan sedimen di sungai bawah tanah Bribin Gunungkidul. Sampling dilakukan pada bulan Maret dan September 2004 di dua lokasi secara grab sample. Penentuan logam berat dengan metode Aktivasi Neutron (AAN), penentuan senyawa DDT dengan metode kromatogafi gas (GC) dan senyawa karbofuran dengan kromatografi cair kinerja tinggi (HPLC). Hasil analisis yang diperoleh, sampel air mengandung logam $\mathrm{Ca}, \mathrm{Mg}, \mathrm{Mn}, \mathrm{Fe}$ dan $\mathrm{Hg}$, serta karbofuran. Sampel sedimen terdeteksi unsur-unsur $\mathrm{Ca}, \mathrm{Mg}, \mathrm{Mn}, \mathrm{Fe}, \mathrm{Hg}, \mathrm{Cd}, \mathrm{Cr}$, Co dan senyawa karbofuran. Senyawa DDT tidak terdeteksi dalam air maupun sedimen. Hasil perhitungan kadar beberapa unsur dan pestisida yang terdapat dalam sampel ditunjukkan pada musim penghujan lebih kecil musim kemarau untuk sampel air dan sebaliknya untuk sedimen, sedang pengaruh lokasi sampling tidak signifikan. Hasil analisis sampel air akan dibandingkan dengan baku mutu Air Gol B pada SK Gub.DIY/1991 dan SK Keputusan MENKES RI Nomor 907/2002.
\end{abstract}

Kata kunci: Sungai Bribin, logam berat, AAN, karbofuran, HPLC, DDT, GC

\begin{abstract}
EVALUATION of METAL ELEMENTS AND PESTICIDE CONTENT of WATER AND SEDIMENT SAMPLES of BRIBIN UNDERGROUND RIVER AT GUNUNG KIDUL (Part I).Determination of $\mathrm{Ca}, \mathrm{Mg}, \mathrm{Mn}, \mathrm{Fe}, \mathrm{Hg}, \mathrm{Cd}, \mathrm{Cr}, \mathrm{Co}$ elements, compound of Carbophuran and DDT content in sediment and water of Bribin Underground River at Gunung Kidul has been carried out. Sampling has been done in March and September 2004 as grab sample. Determination of heavy metal used Neutron Activation Analysis method (NAA), determination of DDT compound used gas chromatography (GC) method and of carbophuran compound used high performance liquid chromatography (HPLC). Analysis result showed that 5 heavy metals i.e.: $\mathrm{Ca}, \mathrm{Mg}, \mathrm{Mn}$, $\mathrm{Fe}$ and $\mathrm{Hg}$, and also carbophuran have been detected in water sample. In sediment sample have been detected heavy metals of $\mathrm{Ca}, \mathrm{Mg}$, $\mathrm{Mn}, \mathrm{Fe}, \mathrm{Hg}, \mathrm{Cd}, \mathrm{Cr}, \mathrm{Co}$ and carbophuran compound. DDT compound has not been detected in sediment as well as water samples. The concentrations of pesticide and elements of the water samples in wet season were less than that of dry season, and reverse with that of sediment samples. The influence of sampling locations was not significance. Result of water analysis will be compared to standard quality of Water of B group stated by Governor of Yogjakarta Special Province (SK Gubernur DIY /1991) and Health Ministry of Republic of Indonesia (MENKES RI Number 907/2002).
\end{abstract}

Keywords: Underground River, heavy metal, NAA, carbophuran, HPLC, DDT, GC

\section{PENDAHULUAN}

$A$ ir merupakan salah satu kebutuhan yang penting bagi kehidupan di samping tanah dan udara. Peranan air bagi kehidupan tidak pernah dapat digantikan oleh bahan lain. Air memegang peranan penting dalam segala aspek kehidupan, baik secara eksternal (untuk keperluan transportasi, pertanian dan lain-lain) maupun secara internal (untuk keperluan minum, melarutkan bahan makanan dan lain-lain).

Kabupaten Gunung Kidul merupakan salah satu kabupaten yang memiliki wilayah sekitar dua perlima dari wilayah Daerah Istimewa Yogyakarta. Ciri khas melekat yang ada hingga saat ini bahwa Gunung Kidul identik dengan kekeringan air, karena tanahnya adalah suatu wilayah yang berbatuan, pada umumnya batuan gamping (limestone). Tercatat di tahun 1987, bencana kekeringan diderita oleh sekitar 193.900 jiwa di 7 kecamatan wilayah Kabupaten tersebut ${ }^{[1]}$. Untuk memenuhi kebutuhan akan air, penduduk kawasan ini rela melakukan apa saja. Mereka mengkonsumsi air dari telaga-telaga yang ada sekalipun di telaga tersebut juga berlangsung

Agus Taftazani dkk. GANENDRA, Vol. VIII, No. 1， Januari 2005 
aktivitas mandi, cuci dan memandikan ternak. Juga sumber-sumber air lainnya seperti gua-gua yang terdapat aliran sungai bawah tanah yang ratusan meter dalamnya.

Air bawah tanah di daerah karst (batu gamping), mempunyai sistem hidrologi yang berbeda dengan daerah non karstik. Hal ini berhubungan dengan sifat fisik-kimia batu gamping. Batu gamping bersifat porous, dan langsung meluluskan air hujan yang jatuh di permukaan tanah melewati rekahan-rekahan pelapisan batuan vertikal dan horizontal sehingga tidak memungkinkan terdapatnya air di permukaan. Air yang mengalir di bawah permukaan akan terakumulasi dalam suatu pola aliran tertentu sebagaimana layaknya sungai permukaan, dengan melewati lorong-lorong gua menjadi sungai bawah tanah. Dari kondisi batu gamping yang melandasi daerah Gunung Kidul tersebut, maka air permukaan sulit didapatkan, namun air dari sungai bawah tanah cukup banyak tersedia. Kondisi kekeringan di Gunungkidul terutama terjadi pada daerah di sebelah selatan hingga ke pantai selatan. Hal ini tidak sesuai dengan bagian bawah permukaan tanah yang terdapat beberapa buah aliran sungai bawah tanah. Jumlah sungai bawah tanah secara pasti belum diketahui, namun dibeberapa lokasi seperti Bribin, Seropan, Ngobaran dan Baron terdeteksi aliran sungai-sungai tersebut ${ }^{[1]}$.

Air merupakan sumber daya alam yang dapat diperbarui atau dipulihkan secara terus menerus melalui siklus hidrologi yang berlangsung secara alami.

Kegiatan penduduk di Kab.Gunungkidul selain petani juga pengrajin logam maupun nonlogam dan penambang batu galian. Sumber pencemaran yang mungkin terjadi di daearah tersebut antara lain:

- $\quad$ Pestisida, yang masih digunakan oleh sebagian petani di sebagian lokasi tertentu.

Air limbah industri kecil, bengkel, rumah tangga, rumah sakit, pasar, perkantoran, dan lokasi pertambangan yang mungkin masih mengandung logam berat dan senyawa organik berbahaya yang belum/telah dikelola. Fe.

Air sungai/tanah daerah karst mempunyai kesadahan tinggi yang mengandung unsur $\mathrm{Ca}, \mathrm{Mg}$ dan juga

Berbagai jenis polutan yang masuk ke dalam sub sistem lingkungan sebagai akibat buangan, dapat digolongkan menjadi 2 golongan, yaitu: Degradable dan Non degradable $e^{[2]}$. Buangan non degradable (konservatif) yaitu buangan yang tidak berubah pada proses biologis, kimia dan fisika. Buangan tersebut antara lain: garam, senyawa kimia organik, buangan radiologi, kimia organik yang menetap, suspensi koloid dan logam berat ${ }^{[2]}$. Kontaminasi yang terbentuk dari buangan tersebut dapat berbahaya terhadap kesehatan manusia.

Dengan latar belakang tersebut maka diperlukan suatu kajian untuk mengetahui kandungan logam berat yang terdapat dalam aliran sungai bawah tanah Bribin yang terdapat di Kabupaten Gunung Kidul. Kajian tersebut dilakukan dengan mengambil sampel air yang merupakan wakil habitat dari komponen ekosistem aliran sungai bawah tanah Bribin ${ }^{[3]}$. Sehingga diharapkan dengan pola pengelolaan aliran sungai bawah tanah Bribin secara terintegrasi dapat mempertahankan produktivitas sumber daya perairan dan kelestarian fungsi lingkungan, di samping juga untuk menunjang kesejahteraan manusia. Kegiatan penelitian ini dibatasi dalam hal: Uji kualitas perairan sungai Bribin di bawah tanah, meliputi analisis air dan sedimennya dengan parameter kandungan logam berat ( $\mathrm{Ca}, \mathrm{Mg}, \mathrm{Mn}, \mathrm{Fe}, \mathrm{Cd}, \mathrm{Cr}$, Co dan $\mathrm{Hg}$ ) dan kandungan pestisida (senyawa DDT dan Karbofuran), kemudian dibandingkan dengan baku mutu Air Bersih pada SK Gubernur DIY/1991 ${ }^{[4]}$ dan Keputusan MENKES RI Nomor 907 Tahun $2002^{[5]}$ sehingga dapat dimanfaatkan sesuai dengan klasnya. Pengambilan sampel air dan sedimen dilakukan di 2 lokasi yang saling mirip dan di dua musim (kemarau dan penghujan), sehingga dapat dipunyai data kualitas air didua musim maupun didua lokasi untuk dievaluasi.

Data yang diperoleh akan dihimpun dalam program induknya (Integrated Water Resource Management, IWRM 2002-2009) yang membahas dalam banyak aspek dan parameter.

\section{TATA KERJA}

- Sampling di lokasi 1dan 2 di sungai Bribin secara grab sampling, dilakukan 1 kali pada musim penghujan (Maret 2004) dan 1 kali pada musim kemarau (September 2004).

- Analisis logam berat $\mathrm{Ca}, \mathrm{Mg}, \mathrm{Mn}, \mathrm{Fe}, \mathrm{Hg}, \mathrm{Cd}, \mathrm{Cr}$, Co, dengan metode Analisis Aktivasi Neutron (AAN) ${ }^{[6]}$ 
- Analisis Karbofuran dengan metode Kromatografi Cair Kinerja Tinggi (HPLC) $)^{[]}$

- Analisis DDT dengan metode gas kromatografi $(\mathrm{GC})^{[8]}$<smiles>Clc1ccc(C(c2ccc(Cl)cc2)C(Cl)(Cl)Cl)cc1</smiles>

Strukur kimia DDT (Dichloro-diphenyl-trichlorethane).<smiles>CNC(=O)Oc1cccc2c1OC(C)(C)C2</smiles>

Struktur kimia Karbofuran ((2,3-dihidro-2,2-dimetil-7-benzofuranil metil karbamat)

\section{Bahan}

Sampel air dan sedimen dari sungai bawah tanah Bribin, standar logam $\mathrm{Ca}, \mathrm{Mg}, \mathrm{Fe}, \mathrm{Mn}, \mathrm{Hg}, \mathrm{Cd}, \mathrm{Cr}, \mathrm{Co}$, $\mathrm{HNO}_{3}$, vial dan kelongsong polyethylen (PE) serta aseton untuk keperluan metode AAN. Isopropanol, metanol, acetonitril, $\mathrm{NaCl}, \mathrm{n}$-hexan, larutan standar DDT dan Karbofuran serta sampel air dan sedimen dari sungai bawah tanah Bribin untuk penentuan senyawa DDT dan Karbofuran dengan alat GC dan HPLC.

\section{Alat}

Seperangkat HPLC, seperangkat GC, fasilitas Lazy Susan (Reaktor Kartini), seperangkat Gamma Spektrometer Ortec, peralatan preparasi dan peralatan sampling.

\section{Lokasi Sampling}
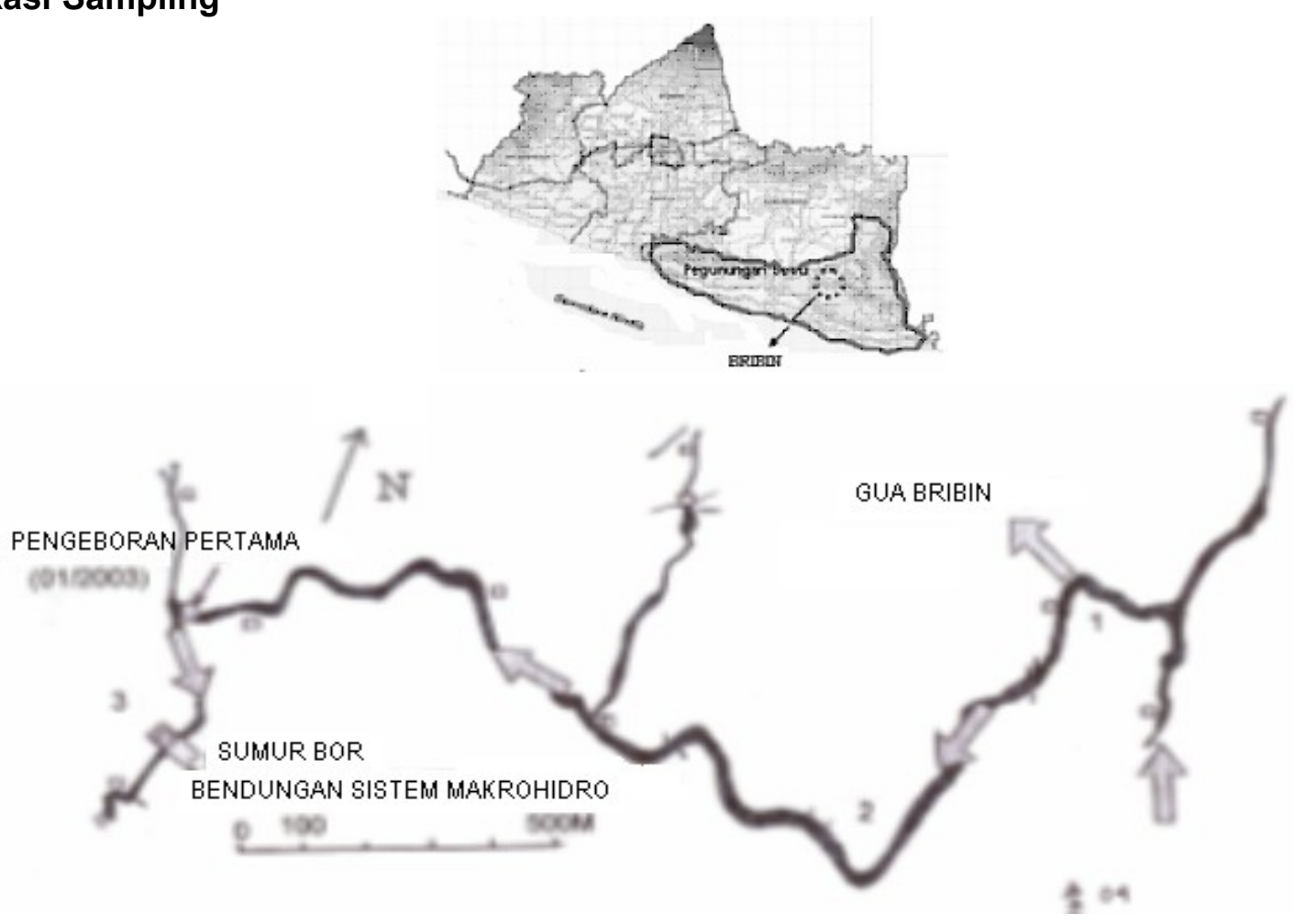

Gambar 1. Lokasi sampling air dan sedimen di Sungai $\operatorname{Bribin}^{[3]}(1,2,3=$ lokasi pengambilan sampel air dan sedimen) 


\section{HASIL DAN PEMBAHASAN}

Hasil analisis kualitatif logam berat dalam air dan sedimen sungai bawah tanah Bribin Kecamatan Semanu, Kabupaten Gunungkidul, dengan metode AAN dapat dilihat pada Tabel 1. Data Tabel 1 menunjukkan ada 4 unsur ( $\mathrm{Ca}, \mathrm{Mg}, \mathrm{Hg}$ dan $\mathrm{Mn}$ ) yang terdeteksi dalam sampel air serta 4 unsur $\mathrm{Cr}, \mathrm{Cd}$, Co dan $\mathrm{Fe}$ yang tidak terdeteksi, baik di lokasi 1 (25 m di atas dam lama) dan lokasi 2 (danau/kedung pertama antara dam lama dan calon dam baru yang cukup dalam dan sulit didapat sedimennya). Unsur yang tidak terdeteksi dalam sampel air diduga kadarnya lebih kecil limit deteksi $\left(\mathrm{L}_{D}\right)$ oleh sistem $\mathrm{AAN}\left(\mathrm{L}_{\mathrm{D}} \mathrm{Hg}=0,0505 \times 10^{-3} \mathrm{ppm}, \mathrm{Ca}=256,54 \times 10^{-3} \mathrm{ppm}\right.$, $\mathrm{Cr}=0,224 \times 10^{-3} \mathrm{ppm}, \mathrm{Cd}=4,475 \times 10^{-3} \mathrm{ppm}, \mathrm{Fe}=4,21 \times 10^{-3} \mathrm{ppm}$ dan $\left.\mathrm{Co}=0,0041 \times 10^{-3} \mathrm{ppm}\right)$. Data Tabel 1 juga menunjukkan adanya delapan (8) unsur terdeteksi dalam semua sampel sedimen, dari dua lokasi sampling, kecuali unsur Cd, baik sampling bulan Maret maupun September 2004.

Jenis logam yang terdeteksi di dalam sampel sedimen lebih banyak dibanding sampel air, hal ini disebabkan oleh sifat perairannya yang tenang dengan pergerakan arus kecil, sehingga pengadukan sedimen oleh arus air yang terjadi relatif kecil. Keadaan ini memperbesar kesempatan senyawa logam/koloid tersebut untuk mengendap di dasar perairan.

Tabel 1. Data kualitatif unsur-unsur yang terdapat dalam sampel Air sungai bawah tanah Bribin, Yogyakarta (Waktu cacah 2000 detik dengan waktu iradiasi 12 jam dan flux neutron $1,05 \times 10^{11} \mathrm{n} \cdot \mathrm{det}^{-1} . \mathrm{cm}^{-2} \mathrm{di}$ lokasi Lazy susan).

\begin{tabular}{|c|c|c|c|c|c|c|c|c|c|c|c|}
\hline \multirow{4}{*}{ No } & \multirow{4}{*}{$\begin{array}{l}\text { Nama } \\
\text { Isotop }\end{array}$} & \multirow{4}{*}{$\begin{array}{c}\text { Tenaga } \\
(\mathrm{KeV})\end{array}$} & \multirow{4}{*}{ Waktu paruh } & \multicolumn{8}{|c|}{ Sampel air } \\
\hline & & & & \multicolumn{4}{|c|}{ Sampling 17 Maret 04} & \multicolumn{4}{|c|}{ Sampling 8 September 04} \\
\hline & & & & \multicolumn{2}{|c|}{ Sampel air } & \multicolumn{2}{|c|}{ Sampel sedimen } & \multicolumn{2}{|c|}{ Sampel air } & \multicolumn{2}{|c|}{ Sampel sedimen } \\
\hline & & & & $\mathrm{L} 1$ & L2 & L1 & L2 & $\mathrm{L} 1$ & L2 2 & L1 & $\mathrm{L} 2$ \\
\hline 1. & $\mathrm{Hg}-197$ & 77,6 & 65 jam & $\mathrm{T}$ & $\mathrm{T}$ & $\mathrm{T}$ & $T$ & $\mathrm{~T}$ & $\mathrm{~T}$ & $\mathrm{~T}$ & $\mathrm{~T}$ \\
\hline 2. & Ca-47 & 160 & 4,7 hari & $\bar{T}$ & $\bar{T}$ & $T$ & $\mathrm{~T}$ & $\mathrm{~T}$ & $T$ & $T$ & $T$ \\
\hline 3. & Cr-51 & 320 & 27,8 hari & $<L_{D}$ & $<L_{D}$ & $T$ & $T$ & $<L_{D}$ & $<\mathrm{L}_{\mathrm{D}}$ & $\bar{T}$ & $T$ \\
\hline 4. & Cd-115 & 338 & 53 jam & $<\mathrm{L}_{D}$ & $\angle L_{D}$ & $T$ & $<L_{D}$ & $<L_{D}$ & $\angle L_{D}$ & $\mathrm{~T}$ & $<\mathrm{L}_{D}$ \\
\hline 5 & $\mathrm{Mg}-27$ & 1014 & 9,45 menit & $T$ & $\mathrm{~T}$ & $T$ & $T$ & $\mathrm{~T}$ & $T$ & $\mathrm{~T}$ & $T$ \\
\hline 6 & Fe-59 & 1098,6 & 45,1 hari & $<\mathrm{L}_{D}$ & $\angle L_{D}$ & $T$ & $\mathrm{~T}$ & $<L_{D}$ & $\angle L_{D}$ & $T$ & $T$ \\
\hline 7 & Co-60 & 1173,1 & 5,24 tahun & $<\mathrm{L}_{D}$ & $<L_{D}$ & $T$ & $\mathrm{~T}$ & $<L_{D}$ & $<L_{D}$ & $T$ & $T$ \\
\hline 8 & $\mathrm{Mn}-56$ & 1810 & 2,58 jam & $T$ & $\mathrm{~T}$ & $T$ & $T$ & $\mathrm{~T}$ & $T$ & $\mathrm{~T}$ & $T$ \\
\hline
\end{tabular}

Keterangan : L1 = Lokasi $1 ;$ L2 = Lokasi $2 \quad \mathrm{~T}=$ terdeteksi M = Maret $2004 \mathrm{~S}=$ September $2004<\mathrm{L}_{\mathrm{D}}=$ lebih kecil dari limit deteksi

Hasil uji kuantitatif, kadar unsur-unsur yang terdeteksi dalam sampel air dapat dilihat pada Gambar 2. Kadar logam $\mathrm{Hg}, \mathrm{Cd}, \mathrm{Cr}$ dan $\mathrm{Co}, \mathrm{Mn}$ dalam sampel air sungai masih di bawah ambang batas yang diijinkan menurut SK Men.Kes RI Nomor 907 Tahun 2002 untuk Air Bersih, sedang kadar logam Mg tidak diatur ambang batasnya. Kadar logam Fe telah melebihi batas ambang baku mutu. Jadi pada umumnya air sungai dapat dijadikan bahan baku air bersih/rumah tangga jika telah diolah dahulu untuk menurunkan kadar logam $\mathrm{Fe}$, terutama pada musim penghujan.

\section{Pengaruh perbedaan lokasi \& waktu sampling}

Kadar beberapa logam dalam sampel air pada Gambar 2 terlihat tidak dipengaruhi oleh perbedaan lokasi sampling (1 dan 2), kecuali kadar logam Fe pada sampling musim kemarau perbedaan cukup nyata. Hal ini memang telah diusahakan dipilih lokasi satu dan dua mempunyai kondisi fisik yang hampir sama (lebar, kedalaman dan arus air).

Kadar beberapa logam dalam sampel air jika dilihat dari fungsi waktu sampling pada Gambar 2 akan terlihat ada perbedaan yang signifikan (alfa $=0,05$ ) dimana kadar logam musim penghujan (Maret) lebih kecil musim kemarau (September), kecuali logam $\mathrm{Cd}$ dan $\mathrm{Cr}$ hampir sama. Perbedaan ini dimungkinkan karena 
adanya air hujan yang masuk ke sungai sehingga terjadi peningkatan $\mathrm{pH}$ air sungai yang berakibat banyak logam ion/koloid akan mudah terendapkan di sedimen, sehingga kadar logam terlarut dalam air menurun.

Beberapa unsur dalam sampel sedimen pada Gambar 3 terlihat kadar unsur-unsur pengambilan pada musim penghujan (Maret) lebih besar musim kemarau untuk lokasi 1. Kejadian ini didukung oleh data Gambar 2, bahwa kadar unsur dalam air pada musim penghujan (Maret)<musim kemarau (September), karena ion logam/koloid banyak yang mengendap dalam sedimen pada pH air tinggi. Data kadar unsur-unsur untuk lokasi 2 (Gambar 2) ditunjukkan kadar unsur fungsi waktu sampling adalah sebaliknya, dimana kadar musim penghujan (Maret) lebih kecil kadar musim kemarau (September). Kejadian ini menimbulkan pertanyaan apakah telah terjadi kesalahan saat sampling dan pereparasi sampel (salah pemberian tanda sampel, terkontaminasi dsb.), atau waktu iradiasi maupun pencacahan dst. Hal ini akan menjadi masukan pada penelitan ke 2 (tahun 2005).

Kandungan semua logam dalam penelitian ini yang tertinggi ditemukan dalam sedimen. Hal ini menunjukkan bahwa akumulasi tertinggi dari logam terjadi pada sedimen, dan memberikan petunjuk bahwa sebagian besar senyawa pada logam yang masuk ke perairan Sungai Bawah Tanah Bribin Yogyakarta berbentuk partikel atau endapan dan hanya sebagian kecil yang terlarut dalam air, bahkan didukung dengan pola arus sungai yang tenang (kecepatan arusnya kecil) menyebabkan zat pencemar mempunyai kesempatan yang kecil untuk didistribusikan secara meluas dan semakin lama semakin tertimbun di dasar sungai. Kondisi perairan yang tenang akan memberikan kemungkinan logam untuk diendapkan.

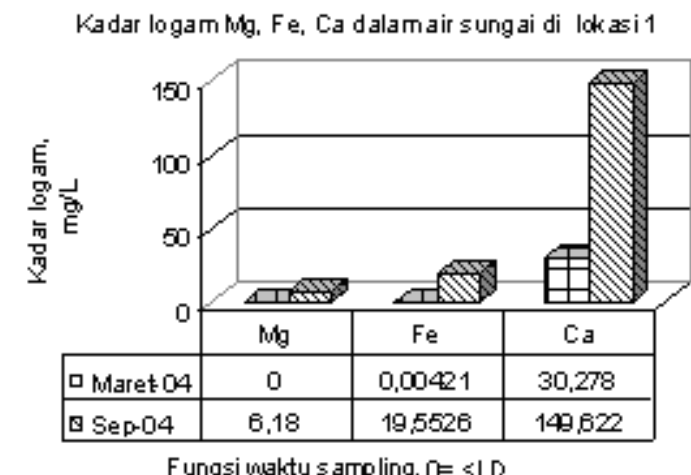

Kadax logan $\biguplus_{1}, C d, \alpha, C o$ dalanair sungai di lokas 2

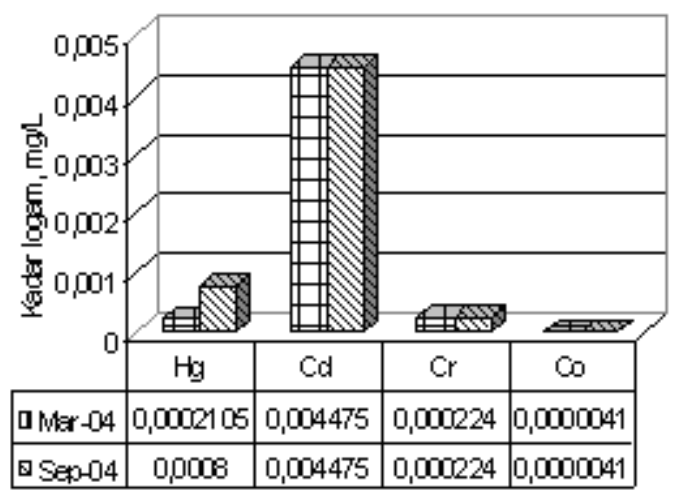

Fungs vertu sarrpling, $0=\angle D$
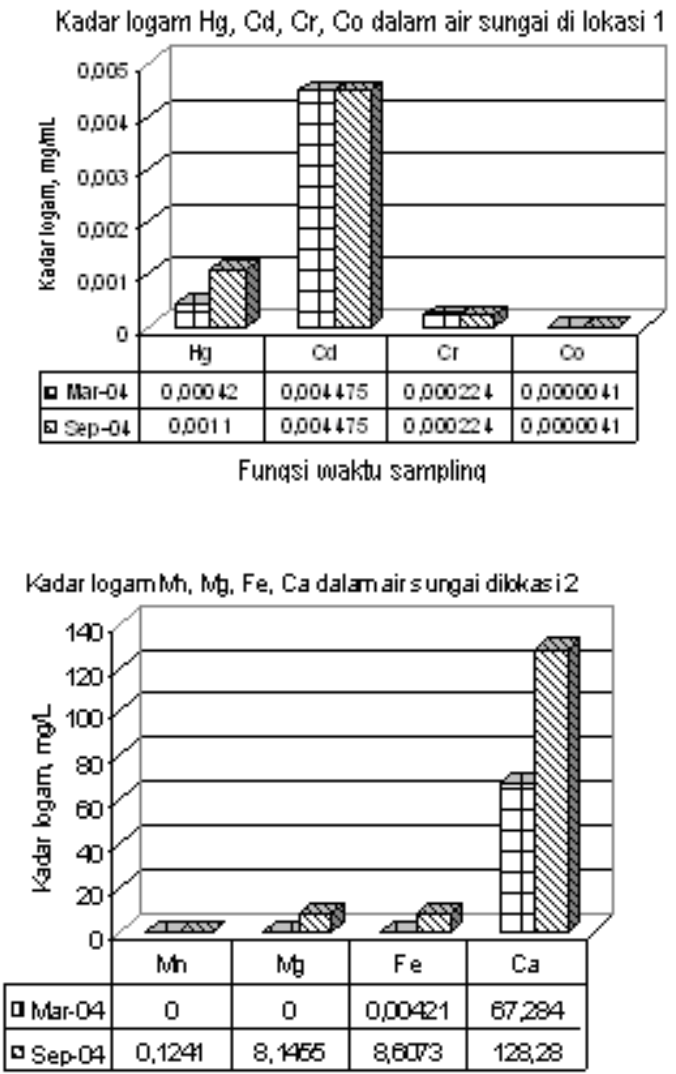

Fungsiuntetusamping, $0=<\omega$

\begin{tabular}{|c|c|c|c|c|c|c|c|c|}
\hline Unsur & $\mathrm{Hg}$ & $\mathrm{Cd}$ & $\mathrm{Cr}$ & $\mathrm{Co}$ & $\mathrm{Mn}$ & $\mathrm{Mg}$ & $\mathrm{Fe}$ & $\mathrm{Ca}$ \\
\hline Batas Ambang Bakumutu Air Bersih $(\mathrm{mg} / \mathrm{L})^{*}$ & 0,001 & 0,005 & 0,05 & - & 0,5 & - & 1,0 & 500 \\
\hline
\end{tabular}

SK Men.Kes RI Nomor 907 Tahun 2002 untuk Air Bersih

Gambar 2. Kadar logam berat $\mathrm{Hg}, \mathrm{Cd}, \mathrm{Cr}$, Co serta $\mathrm{Mn}, \mathrm{Mg}$, Fe, Ca dalam air sungai Bribin di lokasi 1 dan 2, fungsi waktu sampling Maret (penghujan) dan September (kemarau) 2004 
Evaluasi kadar logam berat dan pestisida pada sampel air sungaI Bribin Gunung Kidul fungsi waktu dan lokasi sampling (Bagian I)

Kadar logam $\mathrm{Hg}, \mathrm{Cd}, \mathrm{Cr}$ dan $\mathrm{Co}$ dalam sedmen sungai dilokasi 1

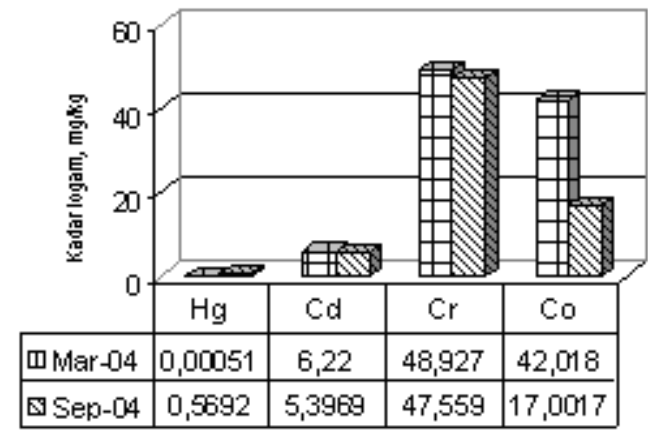

variasi maktu sampling

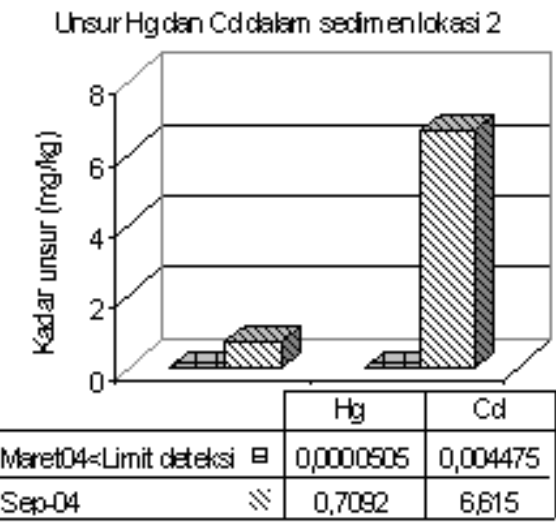

Fungsi wedtusampling Sampel Marets Limit deteds

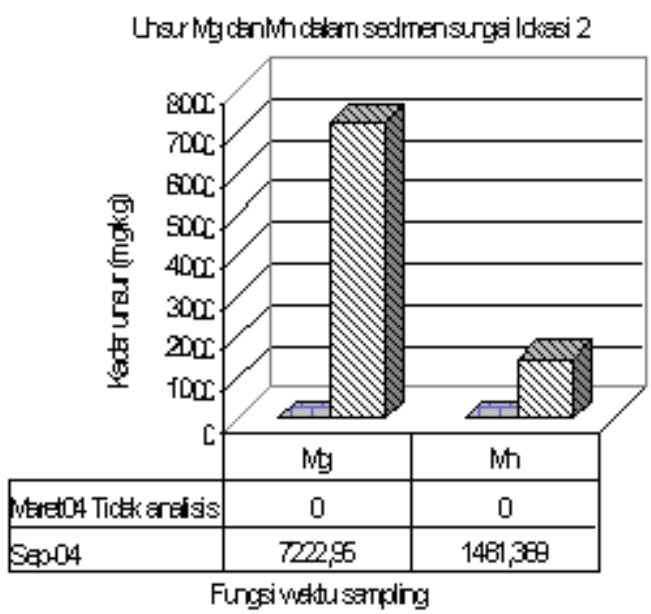

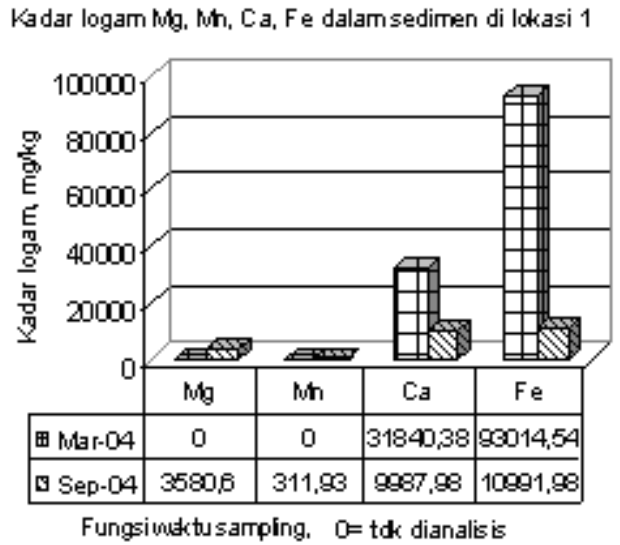

Unsur $\alpha$ dan Co dalam sedirmen sunga lokas 2

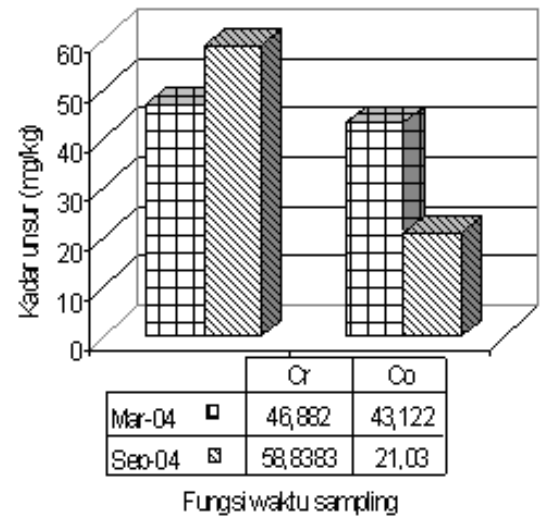

Kadar unsur $\mathrm{Ca}, \mathrm{Fe}$ dalam sedimen sunqai lokasi 2

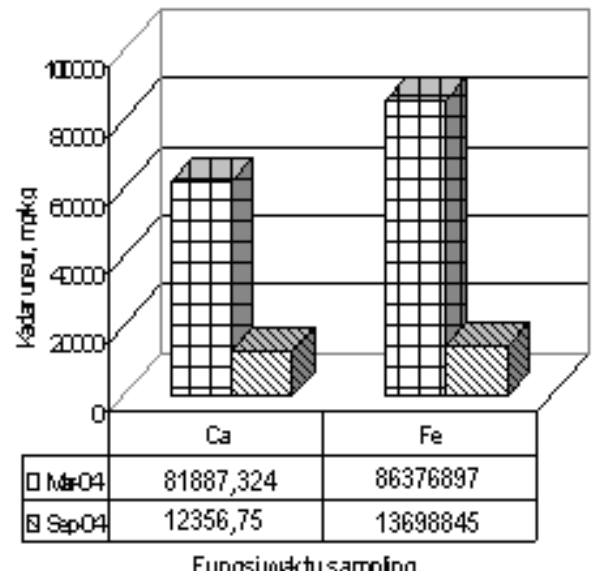

Gambar 3. Kadar logam $\mathrm{Hg}, \mathrm{Cd}, \mathrm{Cr}$, Co serta Mg, Mn, Fe dan Ca dalam sedimen sungai di lokasi 1 dan 2. (Bakumutu untuk sedimen belum ada peraturannya)

Dari Tabel 2 dapat dilihat bahwa DDT tidak terdeteksi dalam sampel air dan sedimen dikarenakan DDT tersebut berada di bawah limit deteksi alat yang digunakan yaitu Kromatografi Gas (GC) 
Tabel 2. Data kromatografi pada sampel air dan sedimen untuk DDT

\begin{tabular}{|c|c|c|c|}
\hline \multirow{2}{*}{ Sampel } & \multirow{2}{*}{ Lokasi Pengambilan } & \multicolumn{2}{|c|}{ Konsentrasi DDT (ppm) } \\
\cline { 3 - 4 } & & Sampling 17 Maret 04 & Sampling 8 September 04 \\
\hline \multirow{3}{*}{ Air } & 1 & Ttd & Ttd \\
\cline { 2 - 4 } & 2 & Ttd & Ttd \\
\cline { 2 - 4 } & 3 & Ttd & Ttd \\
\hline \multirow{3}{*}{ Sedimen } & 1 & Ttd & Ttd \\
\cline { 2 - 4 } & 2 & Ttd & Ttd \\
\cline { 2 - 4 } & 3 & Ttd & \multicolumn{2}{|c|}{} \\
\hline
\end{tabular}

Keterangan : $\mathrm{Ttd}=$ Tidak terdeteksi

Terlihat dalam Gambar 4 pada umumnya kadar karbofuran dalam sampel air pada musim penghujan (Maret) lebih kecil dari pada musim kemarau (September) dan berakibat kadar Karbofuran dalam sedimen akan lebih besar sebagaimana di lokasi 1, tetapi tidak terjadi pada sedimen dari lokasi 2 hal ini sama dengan kecenderungan kadar logam dalam air. Kejadian lokasi 2 data pada Gambar 4 ini sama dengan data pada Gambar 3 (kadar logam dalam sedimen), artinya ada dugaan kesalahan pada waktu sampling, preparasi, iradiasi atau pencacahan/analisis.

Konsentrasi karbofuran dalam sampel air dan sedimen dari masing-masing lokasi dan tanggal pengambilan yang berbeda (Gambar 4) masih di bawah batas ambang bakumutu kualitas air (5 mg/L) Menurut Keputusan MENKES RI Nomor 907 tahun 2002 sehingga air sungai bawah tanah Bribin, Gunung Kidul Yogyakarta dapat dianggap aman dari aspek senyawa karbofuran dan DDT.
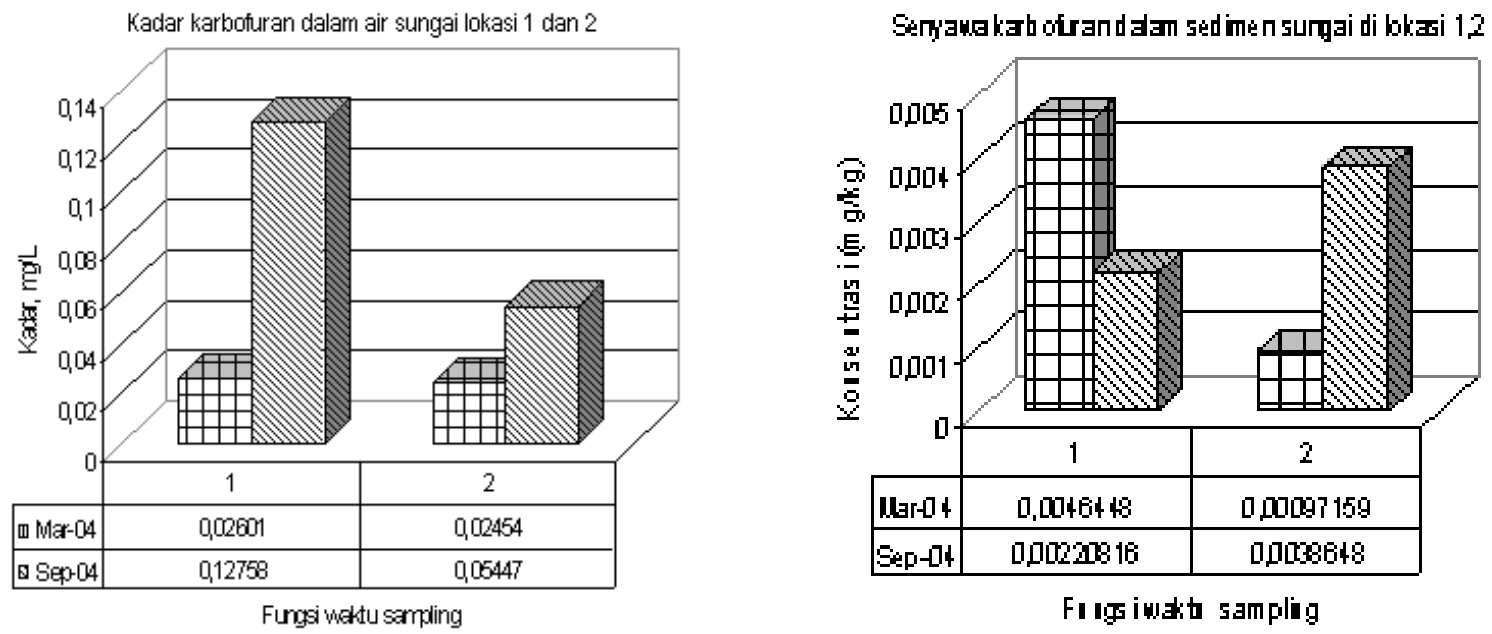

(Baku Mutu Kualitas Air Bersih, Menurut MENKES RI Nomor $907 / 2002$ adalah 5 mg/L)

Gambar 4. Kadar karbofuran dalam sampel air dan sedimen sungai di lokasi sampling 1 dan 2 pada sampling Maret (Penghujan) dan September (Kemarau) 2006

Dari hasil pengukuran sampel air dan sedimen, dapat disimpulkan untuk DDT tidak terdeteksi oleh alat Kromatografi Gas (GC), ini merupakan kabar baik bagi masyarakat Gunung Kidul tetapi jangan terus menutup mata, karena ada kemungkinan senyawa organoklor lain bisa saja terdapat dalam air dan sedimen tersebut, untuk itu perlu dilakukan pengujian lebih lanjut.

\section{KESIMPULAN}

Berdasarkan dari hasil pengamatan yang dilakukan pada sampel air dan sedimen yang berasal dari sungai Bribin, maka dapat disimpulkan beberapa hal sebagai berikut :

1. Pada sampel air sungai telah terdeteksi senyawa Karbofuran serta unsur $\mathrm{Ca}, \mathrm{Mg}, \mathrm{Mn}$, Fe dan $\mathrm{Hg}$ yang masih lebih kecil ambang batas yang dijijnkan untuk keperluan bahan air minum menurut baku mutu 
Keputusan Menteri Kesehatan Republik Indonesia No. 907/MENKES/SK/VII/2002, sedang senyawa DDT tidak terdeteksi dalam sampel air sungai.

2. Senyawa Karbofuran maupun unsur $\mathrm{Ca}, \mathrm{Mg}, \mathrm{Mn}, \mathrm{Fe}, \mathrm{Hg}, \mathrm{Cd}, \mathrm{Cr}$ dan $\mathrm{Co}$ telah terdeteksi dalam sampel sedimen. Bakumutu untuk sedimen belum ada aturannya di Indonesia. Senyawa DDT tidak terdeteksi dalam sampel sedimen.

3. Pengaruh waktu sampling terhadap kadar unsur logam maupun senyawa Karbofuran pada sampel air ditunjukkan bahwa pengambilan musim penghujan (Maret) lebih kecil musim kemarau (September). Sampel sedimen mempunyai data yang sebaliknya, kecuali pada lokasi sampling 2.

4. Air bawah tanah sungai Bribin Gunung Kidul dapat dimanfaatkan untuk air bersih yang digunakan untuk keperluan rumah tangga dan bahan air minum bagi kebutuhan masyarakat daerah sekitarnya, jika air tersebut diproses menjadi air bersih, terutama proses penurunan kadar Kalsium ( $\mathrm{Ca}$ ) dan Besi (Fe).

\section{DAFTAR PUSTAKA}

1. ANONIM. Presentasi PDAM dalam 1st Workshop on Underground Water Resources Management, in Karst Area, Gunungkidul DIY. BATAN-Univ Karlsruhe-Pemda DIY. Yogyakarta, Maret 2004.

2. DARMONO. LOGAM DALAM SISTEM MAKHLUK HIDUP, UI Press, Jakarta 1995.

3. TAFTAZANI, AGUS. Water Resource Management in Karst Area. Program P3TM-BATAN, Yogyakarta 2004.

4. ANONIM. Baku Mutu Air Bersih pada SK Gubernur DIY/1991. Yogyakarta 1991

5. ANONIM. Baku Mutu Kualitas Air Bersih, Menurut MENKES RI Nomor 907 Tahun 2002. Jakarta 2002.

6. TAFTAZANI, A., Unjuk Kerja AANI Pada Analisis Logam Berat Dalam Cuplikan Lingkungan, Prosiding Seminar Sains dan Teknologi Nuklir, PPTkN-BATAN, Bandung (2001), halaman 263-273.

7. LIHAWA, MUHAMAD. Karbamat (Karbofuran), Diktat Matakuliah Toksikologi Insektisida Program Pasca Sarjana Jurusan Ilmu Pertanian UGM, Yogyakarta 2004.

8. RAHAYU,T.P., BAMBANG. Uji Beberapa Insektisida Terhadap Thrips Teh di Perkebunan Teh PT. Pagilaran Jawa Tengah, Fak. Petanian UGM, Yogyakarta, 1986. 